\title{
Roles and impacts of non-governmental organizations in Natura 2000 implementation in Hungary and Poland
}

\author{
JOANNA CENT ${ }^{1,2 *}$, CORDULA MERTENS ${ }^{3 *}$ AND \\ KRZYSZTOF NIEDZIAŁKOWSKI ${ }^{4,5 *}$ \\ ${ }^{1}$ Jagiellonian University, Institute of Environmental Sciences, ul. Gronostajoma 7, 30-387 Krakóm, Poland, \\ ${ }^{2}$ Jagiellonian University, Institute of Sociology, ul. Grodzka 52, 31-044 Krakóm, Poland, ${ }^{3}$ St István University, \\ Institute of Environmental and Landscape Management, Páter K. u. 1, H-2103 Gödöllö, Hungary, ${ }^{4}$ Mammal \\ Research Institute Polish Academy of Sciences, ul. Waszkiemicza 1, 17-230 Biatomieża, Poland, and \\ ${ }^{5}$ Sustainability Research Institute, School of Earth and Environment, University of Leeds, UK
}

Date submitted: 9 October 2011; Date accepted: 19 October 2012; First published online:

25 January 2013

THEMATIC SECTION

Biodiversity Governance

in Central and Eastern

Europe

\section{SUMMARY}

The ecological network of Natura 2000, an European Union (EU) initiative to halt biodiversity loss across Europe, has dominated biodiversity governance in the new EU member states in recent years, as implementation was a condition of accession. Nongovernmental organizations (NGOs) have generally assisted Natura 2000 implementation. In two Central and Eastern European countries (Poland and Hungary), NGOs became involved in different ways; this paper seeks to analyse and explain these national differences by researching the theoretical background of policy networks and advocacy coalitions in both countries. In Hungary, NGOs worked closely with governmental authorities and contributed significantly to site selection. In Poland, NGOs initially opposed government plans, but later moved toward close cooperation with public institutions; this resulted in a significant expansion in the area and number of designated Natura 2000 sites. In both countries, NGO influence increased during the Natura 2000 process owing to the establishment of multi-level policy networks with the European Commission and public institutions, based on resource dependencies and shared beliefs. In postsocialist countries, the progression from governmentmonopolized biodiversity conservation implies a growing importance and contribution of NGOs, and their ability to use resources appropriately in the new governance contexts.

Keymords: advocacy coalitions, biodiversity, multi-level governance, Natura 2000, non-governmental organizations, policy networks

\footnotetext{
*Correspondence: Joanna Cent Tel: +48 126645204 Fax: +48 126646912 e-mail: joanna.cent@uj.edu.pl, Cordula Mertens Tel: +36 28522002269 Fax: +36 28415383 e-mail: cordula.mertens@kti.szie.hu, Krzysztof Niedziałkowski e-mail: kniedz@ibs.bialowieza.pl
}

\section{INTRODUCTION}

Biodiversity conservation in Central and Eastern Europe (CEE) has attracted attention from scholars of environmental governance, mainly because of the far-reaching effects of the post-communist transition and the recent accession to the European Union (EU), which have led to changes in structures of state power and the development of civil society (Börzel \& Buzogány 2010a; Kluvánková-Oravská et al. 2009; Tickle \& Clark 2000). CEE's natural heritage is associated with extended arrays of national protected areas and a larger share of traditional agriculture than in Western Europe (Lawrence 2008). While the traditional mode of conservation in this region is science-based top-down management, the recent accession to the European Union (EU) brought a demand for introducing new conservation approaches and policies (Lawrence 2008). As the Natura 2000 network (hereafter N2000), based on the Birds Directive (79/409/EEC, see URL http://ec.europa.eu/environment/nature/legislation/ birdsdirective/index_en.htm) and the Habitats Directive (European Community Directive on the Conservation of Natural Habitats and of Wild Fauna and Flora 92/43/EEC, see URL http://ec.europa.eu/environment/ nature/legislation/habitatsdirective/index_en.htm), increasingly put agricultural land and managed forests under protection, the implementation of EU biodiversity policy resulted in increased land use conflicts (Grodzińska-Jurczak \& Cent 2011), similar to those in the 'old' EU member states (MSs) (Alphandéry \& Fortier 2001; Hiedanpää 2005; Keulartz 2009; Rauschmayer et al. 2009; Ferranti et al. 2010). At the same time, environmental groups were dissatisfied with state actions (Arany \& Tripolszky 2007; Börzel \& Buzogány 2010a).

While, for example, in France, state authorities have addressed increasing environmental conflicts through stakeholder participation (Rauschmayer et al. 2009), in CEE such attempts have been largely unsuccessful (Niedziałkowski et al. 2012). Despite this, Paavola et al. (2009) stated that environmental governance in the region, with its still visible tension between old hierarchical and new decentralized institutions, has a potential for evolving towards a more multilevel and participatory mode. To understand this potential better, it is important to study the changing roles 
of different actors. This paper looks at the implementation of N2000 in Hungary and Poland, and the role of nongovernmental organizations (NGOs) therein. The major differences in implementation of N2000, and especially in the involvement of NGOs between the two countries (Börzel \& Buzogány 2010a), may reveal the mechanisms behind the shift in environmental governance practices.

Biodiversity conservation, like other policy domains, is shaped by a number of actors trying to influence the policymaking process. For that purpose actors use their resources, such as finances, expertise and access to public officials. Due to sectoral fragmentation within the government, policymakers of a specific domain tend to favour key professional groups whose views are regarded as legitimate and important (Hall 1993). Consequently, ideas and beliefs shape policy decisions, along with the actors' agency and structural inequalities.

The EU has facilitated NGO engagement in the implementation of N2000. In most countries, the Special Protection Areas for birds (SPAs) were based on BirdLife's inventory of Important Bird Areas (IBAs) (EC [European Commission] 2002). The designation of Special Areas of Conservation (SACs) for habitats and species other than birds included a 'biogeographical seminar', namely bilateral negotiations between the EC and the MSs, where the country's proposal was discussed with EC experts, MS officials, independent experts and stakeholder representatives (EC 2002). NGOs were able to participate as stakeholders and submit their 'shadow lists' of sites to the EC, as alternatives to those proposed by their respective national governments. These shadow lists were then discussed together with the MS's official proposals. The policy outcomes of N2000 implementation were seen to result from the top-down influence of the EU, the bottom-up actions of NGOs and the impact of horizontal policy networks, while cooperation between the state and NGOs was portrayed as limited to consultation and delegation of technical skills (Börzel \& Buzogány 2010a).

We analysed the role of NGOs in Hungary and Poland by applying two models of policy processes emphasizing the importance of groups in policymaking, namely policy network analysis (PNA) (Rhodes 1990; Marsh \& Rhodes 1992) and the advocacy coalition framework (ACF) (Sabatier 1998; Sabatier \& Jenkins-Smith 1999). PNA focuses on interdependencies between the actors involved in policymaking (interest groups and government) and their influence on policy development. Policy networks are defined as complexes of organizations connected by resource dependencies. They vary from tight policy communities to loose issue networks. They are established when interest groups gather around governmental departments to influence policy, and the government involves them in policymaking to use their resources for its purposes (O'Riordan \& Jordan 1996).

Actors in policy networks manoeuvre for advantage, using their resources (legal, financial, political, organizational and informational) to maximize their influence, whilst trying to remain independent of other actors' resources (Marsh \& Rhodes 1992). The structure of policy networks impacts not only on policy outcomes, but also on the behaviour of the actors involved. Policy networks may change mainly because of external factors, such as economic, ideological or technological changes affecting existing resources and power relations (Marsh \& Rhodes 1992). Policy networks, and especially policy communities, defined by routine formalized relationships and incremental policymaking, promote continuity and prevent change by excluding initiatives that could undermine dominating interests. Consequently, the approach is mainly criticized for its presumed limited ability to account for radical policy change of irregular character and its impact on the policy networks themselves (Jordan \& Greenaway 1998; Peters 1998; Smith 2000).

The ACF emphasizes the role of ideas and information in shaping policy change. It assumes that actors within a particular policy subsystem can be aggregated into a number of advocacy coalitions, each including people from various state and non-state organizations that share a set of normative and causal beliefs and engage in coordinated activity. The belief systems of each coalition are hierarchically organized: (1) deep core beliefs include basic philosophical values that apply to all policy domains; (2) policy core beliefs represent a coalition's fundamental values and causal perceptions; and (3) secondary aspects of a coalition's belief system concern the relative importance of different causal factors or the design of specific institutions. The policy core constitutes the fundament of coalitions within a policy domain. Each coalition adopts strategies to alter the behaviour of governmental authorities in line with its policy objectives. According to Sabatier and Jenkins-Smith (1999, p. 122), policy change usually has an incremental character and results from 'policy oriented learning', which through new information and experience affects secondary aspects of the belief system. External shocks are another important source of policy change, but their impact is seen as mediated by interpretative and learning processes within coalitions (Sabatier 1998).

The ACF was mainly criticized for putting too much emphasis on beliefs as a 'glue' of coalitions and ignoring questions of coalition structure, stability and strategic positions (Schlager 1995). Szarka (2010, p. 849) stressed that beliefs are insufficient to explain coalition behaviour and turned to interests for supplementing the ACF seeing 'interaction between ideas and interests as an intermediary variable for explaining policy conflict, learning and change'. Similarly, Hysing and Olsson (2008, p. 738) found that 'resource interdependence is an additional [to beliefs] vital factor to understand intra-coalition dynamics'. Smith (2000), comparing the ACF and PNA, pointed to the interplay of resource interdependencies and beliefs in contributing to a partial explanation of policy change and stability. Following these insights, we assumed that both approaches were complementary in explaining policy processes; they provide a theoretical background for understanding the roles of NGOs in the policymaking process and gaining closer 
insight into the relationships between beliefs, interests and resources.

The objectives of this paper are (1) to explain the role of NGOs in the policy process and their impact on the implementation of N2000 in Hungary and Poland, and (2) to establish whether advocacy coalitions and policy network approaches can explain the roles and impacts of NGOs on biodiversity conservation policy in these countries.

\section{METHODS}

This qualitative research consisted of in-depth interviews and a desk study. Interviews were based on a preliminary list of questions (interview guides are provided in Appendix 1, see supplementary material at Journals.cambridge.org/ENC); specific questions varied depending on the interviewee's position and experience. The following topics were discussed in all interviews: the role of the interviewee's organization in the implementation of N2000 (motivations, capacities and actions); perceived importance of N2000 for biodiversity conservation; different stages of the implementation process; interactions with other actors; and problems and conflicts (Appendix 1, see supplementary material at Journals.cambridge.org/ENC). The interviews were recorded and transcribed, or described in detailed field notes. Transcriptions were analysed by selecting and comparing responses that were relevant to the main objectives of the study. We analysed the Hungarian interviews using the coding software MAXQDA. Inferences were drawn and confirmed using analytical matrixes for comparing data (the responses or summary description of responses) between selected groups of actors and specific research themes to identify commonalities and patterns (Miles \& Huberman 1994). This analysis was verified against information on N2000 implementation gleaned from publicly available documents, legal acts, web pages and the literature.

We conducted a total of 27 interviews in Hungary during 2009-2010 and 17 interviews in Poland in 2006 and 2010. Interviewees were NGO members engaged in N2000 implementation at different levels (15 from Hungary and 10 from Poland), public officials (three ministry officials and seven national park officials from Hungary, and five public officials from Poland), and experts (two from Hungary and two from Poland); in total, five Polish and eight Hungarian NGOs were included in the study. A preliminary list of interviewees was derived from available published data (for example, we targeted the authors of shadow lists or other important national documents on N2000, and representatives of state agencies involved in the process). Snowball sampling was used to identify additional interviewees in successive stages of the research; interviewees were asked to recommend a person that should be contacted and interviewed. We continued this process until additional interviews provided little new information.

In Hungary, we addressed the biodiversity governance setting that existed prior to April 2010. Following the election of a new government in April 2010, ministries were merged and several regional authorities reorganized; as this paper was written during this period of reorganization, it remained too soon to analyse this new setting. In Poland, we focused on the designation phase, largely completed by 2009 .

\section{RESULTS}

\section{The role of NGOs in the implementation process in} Hungary

Interviewees distinguished two main phases of N2000 implementation in Hungary: site designation, and establishing site management and monitoring. NGOs played a role in both phases, but their impact was greater in the first phase.

The Hungarian Ministry of Environment and Water (HMoE) was responsible for N2000 designation and maintenance. It was supported by the National Park Directorates (NPs), namely subordinate regional nature conservation administrations responsible for the monitoring and management of protected areas. The task of preparing the N2000 site proposal was delegated to the NPs shortly before accession to the EU; the HMoE then combined the data into a national list, which was submitted to the EC with a few months delay in October 2004, but in time for the biogeographic seminar held in September 2005.

The HMoE asked BirdLife Hungary to prepare a proposal for SPAs. This updated list of the IBAs (Kovács et al. 2002) was then, with minor modifications, accepted by the government. For the SACs, NGOs communicated their proposals to the HMoE before the biogeographical seminar. As most of their suggestions were taken into account and accepted by the EC in the biogeographical seminar, NGOs were satisfied with the final list of N2000 sites, comprising almost $21 \%$ of the country.

To foster N2000 maintenance, NGOs were involved in various activities. Most of the communication with land users was carried out with the involvement of NGOs, financially supported through EU and government funds. NGOs developed a website (www.natura.2000.hu), which all interviewees considered the best online information source on N2000 in Hungarian language. Together with scientific partners, BirdLife Hungary was active in developing models for N2000 site management. Moreover, NGO experts participated in site monitoring, thereby supporting the work of the NPs. Based on their observation of violations of the protection status of sites, regional NGOs initiated court cases in Hungary and informed the EC and the European Parliament. The results of national court cases were mixed because rulings were usually based on procedural criteria; the complaints about the clear-cutting of the Sajólád forest resulted in issuing of an EC warning to Hungary. An environmental law expert explained that the number of court cases had decreased in recent years, probably because developers had become aware of N2000 regulations. 


\section{The role of NGOs in the implementation process in Poland}

In Poland, scientists and NGOs developed the first site proposal of 2004 jointly, but the Polish Ministry of Environment (PMoE) significantly culled the area and number of sites before submitting this to the EC. During the biogeographical seminar, the EC rated the PMoE's official list, covering $11 \%$ of the country's territory, as insufficient (giving inadequate N2000 coverage), and the list was further contested by Polish NGOs. Poland had submitted the least sufficient proposal among all EU MSs (EEA [European Environment Agency] 2007). To supplement the official government proposal, NGOs submitted a 'shadow list' of potential N2000 sites to the EC, in total covering $20 \%$ of Polish territory.

Within Poland, the topic of N2000 became politically highly contentious. According to the NGO members that we interviewed, political leaders tried to limit the area to be designated and to exclude NGOs from the process. An official from the General Directorate for Environmental Protection (GDEP) stated, 'The NGOs became public enemy No. 1' (personal communication 2010). In 2007, Poland was formally urged by the EC to advance $\mathrm{N} 2000$ designation. A new national inventory of proposed sites was undertaken to support the process. In the same year, the ruling party changed. The new government started institutional reforms and invited NGOs to cooperate rather than compete with the state authorities. The development of the final list of proposed sites continued until 2010, including three further biogeographical seminars and several updates of the shadow list. The N2000 network now covers $21 \%$ of the country's territory and most of the sites suggested by NGOs were included in the final list accepted by the EC. Currently management and monitoring schemes for SACs are being developed with less visible NGO involvement; however, NGO experts are often consulted.

\section{Explaining the role of NGOs with the policy network approach: actors and their resources in Hungary}

At the time of N2000 designation, there were four leading NGOs in Hungary working on N2000 at the national level: (1) The Hungarian Ornithological and Nature Conservation Association (BirdLife International partner), (2) the National Society of Conservationists (MTVSz, Friends of the Earth Hungary), which functions as an umbrella organization of green NGOs, (3) WWF (World Wildlife Fund) Hungary, and (4) the Central and East European Working Group for the Enhancement of Biodiversity (CEEweb). BirdLife is a respected ornithological expert organization; many of its members are active birdwatchers. Other NGOs also possessed expertise; they typically employed and were founded by trained nature conservation experts.

At the regional level, there were several NGOs, most of which were members of MTVSz. Two regional NGOs (Nimfea, Society of Conservationists of Eastern Hungary) were especially active in reporting violations of N2000 protection.

CEEweb is an international umbrella organization of CEE NGOs, based in Budapest. It was mandated by the European Habitat Forum, the umbrella organization of nature conservation NGOs in Brussels, to prepare the NGOs of the accession countries for the N2000 process.

Hungarian nature conservation NGOs link to the European level mostly via their umbrella organizations. The sharing of experiences by European NGOs helped Hungarian NGOs to prepare for the N2000 process. Although BirdLife Hungary and MTVSz have a strong local and regional base, national NGO experts, as well as local experts (from NGOs and NPs) considered the exchange between the national and local level to be less smooth and reliable than the one between the national and European level. An explanation given for this difference was that many local NGOs mainly work voluntarily on rather narrow local issues, while the national and Europeanlevel NGOs employ well-trained experts and concentrated on European topics, investing only few capacities into interacting with local NGOs.

Most NGOs had good contacts with the state bodies for nature conservation. Membership in BirdLife Hungary, due to assumed birdwatching skills, was commonly regarded as positive by national park officials when employing national park rangers. In several cases, senior officials of NGOs or state bodies switched positions from working for an NGO to working for state nature conservation bodies and vice versa.

Most officials working for the NPs were trained biologists or ecologists. The HMoE itself employed many nature conservation experts, as well as graduates from other fields. Suffering from budget cuts, the NPs could not employ additional staff for site designation and monitoring of N2000 sites. When preparing the lists, they sometimes sought advice from NGO experts specialized in certain species or habitats. Due to a strict time frame set by the EU, the list of sites was compiled very quickly, which resulted in many inaccuracies; the borders of the officially designated sites often did not fully match the area of actual natural values.

Although the responsibility for N2000 implementation rested with the HMoE, EU subsidies for nature-friendly land management, such as the agri-environmental schemes and support for managing N2000 grassland, were distributed by the Ministry of Agriculture and Rural Development (HMoA). The HMoA was an important actor in the N2000 process, because its regional forestry authorities were responsible for the management of N2000 forests; this competence was the reason for disputes between the $\mathrm{HMoE}$ and the HMoA.

\section{Explaining the role of NGOs with the policy network approach: actors and their resources in Poland}

The NGOs engaged in preparing the shadow list in Poland were: (1) WWF Poland, (2) the Polish Society for Nature Protection 'Salamandra', (3) the Naturalist Club, and (4) the Polish Society for the Protection of Birds 
(OTOP, a BirdLife partner). Some of them were umbrella organizations, representing a number of local and less influential organizations. Other influential NGOs interested in N2000 included: the Association for Nature 'Wolf', the Malopolska Ornithological Association, Pro Natura, the Workshop for All Beings, and the Eagle Conservation Committee. NGOs cooperated intensively with research institutes, especially the Institute of Nature Conservation of the Polish Academy of Sciences in Kraków (IOP). IOP was engaged in N2000 implementation from the beginning; it conducted site selection, inventory and monitoring programmes. Several researchers connected to IOP were members of NGOs that were engaged in the process.

The PMoE was responsible for N2000 implementation until organizational changes in 2008, when a new GDEP with 16 regional branches and a separate budget allocation was established. This, according to all the respondents, made decision-making less dependent on day-to-day politics. The GDEP's staff was mainly recruited from young graduates of environmental science programmes. As assessed by NGO members, the agency gradually built its capacity and experience and started undertaking more independent actions, which also included more intensive cooperation with NGOs.

The State Forests Holding (SFH) was responsible for management and monitoring of N2000 forests. According to the NGOs representatives, at the beginning of the process, foresters were interested in marginalizing the role of N2000 due to perceived conflicts with forest management goals. As argued by some interviewed NGO members, the SFH enjoyed close ties with top ministry officials; the Polish Minister of the Environment (2005-2007) was a forester with a close professional affiliation to this sector.

National park administrations and authorities of other protected areas did not have a significant influence on the implementation of N2000. Local authorities of municipalities participated only in the last year of site designation in face-toface consultations organized by GDEP's regional branches.

As assessed by all interviewees, during the N2000 designation process the $\mathrm{PMoE}$ was dependent on the expertise of NGOs. Financial resources provided by the government and the EU were insufficient for proper site selection with a thorough inventory of the proposed areas. Instead, numerous NGO reports, analyses, data or expertise were used throughout the process, especially for the SPAs. However, interviewed NGOs argued that, in order to avoid relying solely on their support, which was perceived as leading to extended designations, in 2006 the PMoE entrusted the SFH with compiling habitat inventories. According to the NGOs interviewed, due to limited capacity, regional forestry units still had to employ NGO experts to facilitate the survey.

\section{Explaining the role of NGOs with the advocacy coalition framework: beliefs in Hungary}

All interviewees working for Hungarian NGOs and the interviewed experts of state nature conservation bodies shared a world view (policy core beliefs) in which nature and biodiversity were valued as the basis for human life. A national park official (personal communication 2009) stated: 'For me this is the first priority for human existence; without safeguarding the environment, without the natural environment we cannot exist. (...) I think that the first thing is nature, and then come the technical questions'.

Almost half of the interviewed nature conservation experts also believed in an intrinsic value of species. Conservationists (namely nature conservation state officials and NGO members) regarded biodiversity loss as a serious problem that called for immediate protection measures. They often found themselves in a defensive position, threatened by economic interests, especially by the agricultural sector. A HMoE official (personal communication 2009) said: 'The ministry of agriculture (...) have other main objectives, they tend to support more the more intensive agriculture, more intensive farming'.

Interviewed experts stated that the representatives of the agricultural sector and foresters valued nature for the economic benefits of land management. A forestry expert emphasized that foresters have good knowledge and experience in managing forests and that people just needed time to learn and apply new more nature-friendly management practices. According to a HMoA official (personal communication 2009), there should be fewer regulations for forest management to make it less bureaucratic: 'We have to make this process easier. If someone owns a forest and if he or she wanted to cut some trees, it was a very bureaucratic process to get permission to do it. (...) One has to bend the hard bureaucracy. About this the nature conservation is not pleased, they [nature conservationists] say that it's good if there are many permission processes because then they can encroach upon it many times'.

These differences explain the conflict between the $\mathrm{HMoE}$ and the HMoA over the new Forestry Act (Act 2009 XXXVII on Forest Conservation and Forest Management, see URL http://www.complex.hu/kzldat/t0900037. $\mathrm{htm} / \mathrm{t} 0900037$.htm), and the N2000 guidelines included in it. The HMoE officials did not trust the foresters supervised by the HMoA to manage protected forests in a nature-friendly way: 'The agricultural ministry, they say 'we know everything very, very well', and they don' $t$ need advice from our ministry. (...) But we are not satisfied with the draft act of the forestry, so very frustrating. (...) They don't understand what is the actual goal of nature conservation' (HMoE official, personal communication 2009).

Conversely, an official from the land-use sector complained that conservationists sometimes paid more attention to the needs of animals or plants than to people's economic needs. Another reason why the land-using sectors were not very supportive of N2000 was that they felt excluded from the designation process.

When looking at secondary aspects of actors' belief systems, such as preferred policy measures, we identified consistent differences between NGOs and state actors within the 
nature conservation sector. While most NGO interviewees emphasized the importance of involving affected stakeholders from the beginning, only one state nature conservation official did so. NGOs actively informed stakeholders in seminars and via a N2000 website, while the $\mathrm{HMoE}$ pursued a more technical approach towards N2000 implementation, focusing on implementing EU regulations.

\section{Explaining the role of NGOs with the advocacy coalition framework: beliefs in Poland}

All of the Polish NGOs and their scientific partners recognized the intrinsic value of nature and viewed biodiversity as a major concern, which they prioritized over economic goals. Secondary aspects of NGOs beliefs, concerning the preferable design of biodiversity policy, situated N2000 as an important tool for safeguarding valuable areas and species: 'N2000 has practically become the superior form of nature protection although legally it is not the case' (GDEP official, personal communication 2010).

NGOs treated European rules very seriously and paid careful attention to their implementation. While development was perceived as a major driver of biodiversity loss, N2000 was seen as an opportunity to mitigate the threat. The strength of the policy was associated by NGOs with the superior position of the EC in relation to national bodies, which was supposed to ensure that the EU regulations were followed.

While NGOs' beliefs were consistent throughout the process, those represented by the government changed. At the beginning of the implementation process economic goals were clearly prioritized. The Polish Prime Minister (20052007) argued publicly that: 'Such protected areas [as N2000] are scarce in Western European countries and numerous in Poland. N2000 enlarged so much that practically speaking nothing can be built anymore' (Wajrak 2006).

This statement confirms anxiety concerning possible development limitations that N2000 was perceived to entail. The then Minister of the Environment believed nature should serve the purpose of economic growth, stating in a Polish radio broadcast in August 2006 that: '[The government] thinks that Polish environmental resources are unique in Europe, and that they have to stimulate economic development, they have to serve people and become the stimulus of rural areas' (Jan Szyszko, Radio Maryja, broadcast of 9 August 2006). The government's core beliefs were similar to those represented by foresters, who appreciated nature mostly for its utilitarian economic value.

Looking at secondary aspects of the government's belief system, N2000 policy was predominantly perceived as a threat to Poland's economic development, imposed by Western European countries to preserve Polish nature, while their own nature had already been sacrificed for the sake of development. Government representatives perceived Polish national conservation institutions, including national parks and nature reserves, as sufficient for preserving Polish nature while at the same time allowing for developments. Such beliefs on the part of the government, might have contributed to the attempts to limit designation. A GDEP official (personal communication 2010) observed: '[At this time, 2004-2007] political arguments were used. There were no scientific arguments. Implementation of N2000 was "frozen" in general', while a Polish scientist (personal communication 2010) stated: 'When politicians realized that N2000 would have a direct economic impact, strong political pressure started to influence the shape of the network'.

This clearly contradicted NGOs' views that: 'The ministry that is responsible for implementing N2000 does everything they can to interrupt implementing it or to implement fewer areas. This is a story of a conflict between NGOs and the ministry. The one side wants as much as they can get, and the other as little as they can give' (NGO member, personal communication 2006).

Five NGO members believed that government had hindered or at least delayed the selection of N2000 sites as a government strategy to reserve areas for future development. According to one interviewee, the aversion of the right-wing minister towards NGOs might also have stemmed from his perceptions of NGOs as the representatives of the political left wing.

After the government change of 2007, the dominant beliefs of governmental actors changed and advocacy coalitions were reorganized. The new Minister of the Environment started portraying $\mathrm{N} 2000$ as a development chance for Poland, the implementation of which would enable a rapid transfer of EU funds and a faster realization of infrastructure investments: 'Nowicki [the Minister] says that N2000 will be positive and that this law, EIA and N2000, are indicators of [the country's] development' (NGO member, personal communication 2010).

This shift in the position of the PMoE occurred together with reminders coming from the EC and a threat to cease funds for infrastructure development should Poland fail to fulfil the country's environmental obligations. The need to halt biodiversity loss by means of N2000 became recognized as a legitimate governmental responsibility, stated in the new Prime Minister's programme speech in 2007. In 2008, public institutions responsible for N2000 were restructured. The beliefs of the new staff of the GDEP and its regional branches concerning nature conservation were more closely aligned with those of NGOs than those of the forestry or agricultural sector. The development of a good conservation system based on N2000 gradually became the shared goal of both public actors and NGOs: 'For sure, in many cases we fight for common causes. It is just hardly ever communicated to the public' (GDEP official, personal communication 2010).

According to a GDEP official, an important factor enabling this cooperation after a conflict phase was the moderate attitude of NGOs and their ability to limit discussion to content. Positions of former opponents were not polarized to a degree that would hinder future cooperation. To some extent, communication and exchange of information between the coalitions had been present throughout the whole 
implementation process and, as assessed by the GDEP official, gradually this was accompanied by increasing trust.

\section{DISCUSSION}

The capacity of actors to break out of the traditional conflict roles and form new coalitions became important in the implementation of N2000 (Pinton 2001). To overcome conflicts about nature conservation measures, Keulartz (2009) called for investment in long-term communication and cooperation between farmers, foresters, fishers and nature conservationists. The establishment of such new coalitions was difficult in Hungary and Poland. Hungarian NGOs and some researchers made efforts in this direction, but were not fully supported by the state, where the governance setting was dominated by conflicts arising from overlapping responsibilities between nature conservation and land-use authorities. In Poland, apart from NGO activity with regard to N2000 promotion and information, NGO contacts with farmers were scarce. Foresters opposed the implementation of the programme, which hindered coalition building.

The N2000 process led to new interactions between state actors and NGOs and strengthened the position of the third sector in environmental policymaking. In the new European multi-level context, NGOs were provided with new sources of power and bargaining (Weale et al. 2000); and here the NGOs skilfully used these opportunities. CEE NGOs quickly proved to be more akin to their northern European, rather than southern European counterparts (Bell 2004).

Our findings show a complex interplay between actors both on resource (policy networks) and ideological (advocacy coalitions) grounds, and increasingly decisive positions of NGOs in the process. The Hungarian and Polish actors, especially NGOs, did not simply react to EU pressure, but varied their strategies according to the governance setting of each country. Coalitions were formed based not only on resource dependencies between state and non-state actors, which might be an insufficient driver for sustained cooperation of the state and non-state actors in the CEE context (Börzel \& Buzogány 2010b), but also on shared beliefs. Even though the final outcome of the implementation process in terms of percentage of protected area has been quite similar, the processes in Poland and Hungary were different, although the influence of the EU existed in both countries. We found that the differences could be attributed to the dynamics of the process, especially the differing and constantly changing coalitions and networks.

From the perspective of the policy network approach, it is apparent that in Hungary and Poland the implementation of the Birds and Habitats Directive contributed to the creation of policy networks joined by resource interdependencies between the actors (Börzel \& Buzogány 2010b). In both countries, NGOs managed to build considerable expertise in nature conservation (Van Koppen \& Markham 2007). However, the process of policy network construction differed.
In Hungary, the fact that the government was obliged to implement the European legislation fostered cooperation between NGOs and the HMoE. NGOs had expertise, especially concerning the bird areas, which the ministry could build on. Conversely, the HMoE had the power to realize the conservation goals advocated by NGOs. In Poland, the PMoE was dominated by the interests of the major economic organization in the policy sector, namely the SFH, which perceived N2000 as constraining its power to manage the forests. Moreover, the conservation paradigm promoted by N2000 clashed with the development goals preferred by the government in power (Ziemińska \& Szulecki 2010). The PMoE tried to use the SFH's resources, personnel and expertise to carry out an inventory of habitats and species, and thus limit NGO involvement. However, this proved futile, as foresters were unable to carry out the task themselves and eventually had to refer to NGOs for assistance. The new architecture for biodiversity conservation promoted by the EC made NGO involvement practically unavoidable, provided non-state actors were able to act as watchdogs and data-suppliers. This supports the assertion of Weber and Christophersen (2002) that the involvement of environmental NGOs in policymaking on the European level would make it possible for national NGOs to use the opportunities created at the expense of interest of other lobbies (especially forestry and agriculture) that did not get access to earlier stages of policymaking with the Directorate-General for the Environment (DG Environment).

Similar to other EU countries, new European rules allowed Hungarian and Polish NGOs to bypass the politicaladministrative system of their countries in order to realize their goals (Fairbrass \& Jordan 2001; Van Koppen \& Markham 2007). To pursue the implementation of N2000 in Poland despite governmental reluctance, the NGOs formed a close policy network with the EC's DG Environment. The NGOs had expertise that the DG Environment lacked, and could report deficiencies in the site selection process, while the EC had the power to discipline the government. In Hungary, the HMoE's policy was in line with the views of NGOs and, consequently, a close cooperation developed between state and non-state actors. The main state actors of the Hungarian nature conservation administration shared the common goal of NGOs and the DG Environment to increase site protection. The resource dependencies between NGOs and the EC were, therefore, less evident than in Poland. In problematic situations, there remained a possibility of cooperation, as illustrated by a Hungarian regional NGO providing the EC with information about N2000 site violations. NGOs were supported by the EU through project funding, participated in the biogeographical seminar and were encouraged to act as watchdogs. The EU thus had an influence on the means and conditions of NGO activism in CEE (Hicks 2004).

The government change in Poland proved to be a major external factor influencing biodiversity policy, affecting the composition of policy networks and advocacy coalition (Ziemińska \& Szulecki 2010). NGO participation was 
facilitated by the plans of the new minister to implement N2000 as soon as possible to avoid legal proceedings at the European Court of Justice and potential problems with EU funding for infrastructure investments. This made the situation in Poland similar to that in Hungary. The newlyestablished GDEP in Poland, responsible for N2000 and interested in facilitating the implementation process, was much more open to cooperating with NGOs.

Using the theoretical background of advocacy coalitions, in both countries competing beliefs could be identified. Beliefs represented by an advocacy coalition supporting an extensive implementation of N2000 recognized the urgent need to protect biodiversity, appreciated an intrinsic value of nature, and opposed compromising it with developmental goals. This coalition of transnational character included members of NGOs and the DG Environment. The competing advocacy coalition, including national actors, emphasized the utilitarian value of the environment. The main difference between the countries was that, in Hungary, the officials of the $\mathrm{HMoE}$ from the beginning had the same policy core beliefs as NGOs, with whom they were joined by informal contacts. In contrast, in Poland, the government clearly opposed further-reaching biodiversity conservation measures, fearing that they would hinder economic development and infrastructure investments. The PMoE, influenced by governmental economic priorities and foresters, was also reluctant to implement new rules. The advocacy coalition, including the Minister of Environment and its subordinates, gave in to the pressure of the advocacy coalition of NGOs and DG Environment, and was ready to designate some areas as N2000 sites and thus adjust secondary aspects of their belief system, but it resisted decisions on further steps that were seen as necessary by the opponents. When the external shock took place and a new party came into power, the minister, chief nature conservator and general director of the SFH changed and new people adjusted secondary elements of their belief system to accommodate changing structural conditions in the policy domain. Their views seemed to be more closely aligned with the policy core of the pro-N2000 advocacy coalition. A change of actors may be a powerful driver for a shift in dominating beliefs (Sabatier 1998; Elliott \& Schlaepfer 2001) and could, as in the Polish case, contribute to policy shifts.

\section{CONCLUSIONS}

Using the examples of Hungary and Poland, we showed that the NGOs' impact on N2000 implementation was considerable, and without their involvement the area under N2000 designation would have been less extensive. This marks a practical departure from the government-monopolized practices of post-socialist countries and indicates the growing importance of NGOs in biodiversity conservation. The European architecture of biodiversity governance is decisive for NGO activities and determines which roles NGOs can take and what impact their activities may have. The multilevel setting opened new opportunities for NGOs and made them an unavoidable actor in N2000 implementation. NGOs and the DG Environment formed a coalition to challenge the dominant actors at the national level.

PNA and ACF proved helpful in investigating implementation of European biodiversity conservation policy in CEE. This process required NGO resources, which they used differently in accordance with the structure of the policy networks. A coalition between state and nonstate actors in nature conservation formed more easily in Hungary, where the ministry responsible for N2000 implementation did not include other land-use sectors, than in Poland, where the ministry included a strong forestry agency. The PMoE, as envisaged by the PNA, tried unsuccessfully to avoid becoming dependent upon NGO resources, and NGOs entered the policy community despite initial disadvantages. In Hungary, the shared beliefs of the HMoE and NGOs concerning biodiversity facilitated the formation of an environmental coalition. In Poland, the conflict between NGOs and the government, promoted by their contrasting beliefs, contributed to policy-oriented learning of governmental officials to accommodate new ideas underpinning European policy. In 2010, the Hungarian agricultural and environmental ministries were merged into the Ministry of Rural Development, and thus the Hungarian ministerial governance setting is now similar to the situation found in Poland during N2000 designation. Future research on these two countries could therefore further investigate the influence of the departmental structure on environmental policy coalitions and networks.

Both structural characteristics (PNA) and ideological characteristics (ACF) of the policy domain provided complementary explanations of the observed processes. Using both frameworks helped to balance their strengths and weaknesses. Beliefs added dynamics to the stable policy networks and resource dependencies indicated barriers to policy-oriented learning.

\section{ACKNOWLEDGEMENTS}

All authors contributed equally to this paper. We thank all interviewees for their time and the information they shared with us.

The Hungarian case study was conducted with financial support by the European Union (European Commission, Marie Curie RTN GoverNat, Contract No. 0035536). We thank all the members of the ESSRG research group at St István University and the fellows and seniors of the GoverNat project for fruitful discussions.

The Polish study was funded by EUMON (EU-wide monitoring methods and systems of surveillance for species and habitats of Community interest, 6FP Contract No. 6463), BIORESC (Marie Curie Transfer of Knowledge in Biodiversity Research and Conservation, 6FP Contract No. MTKD-CT-2005-029957), the Polish Ministry of Science and Higher Education (Contract No. N N305 353339) and Jagiellonian University (K/ZBW/000771, WRBW/ 
DS/INoŚS760). We are grateful to our colleagues Małgorzata Grodzińska-Jurczak and Hanna Kobierska for their expertise and participation in the field work in Poland. We also thank the anonymous reviewers for their constructive criticism.

\section{References}

Alphandéry, P. \& Fortier, A. (2001) Can a territorial policy be based on science alone? The system for creating the Natura 2000 network in France. Sociologia Ruralis 41: 311-328.

Arany, I. \& Tripolszky, S. (2007) Natura 2000 from NGO point of view: lessons learned in EU-10. Publication by CEEweb for Biodiversity. [www document]. URL http://www. ceeweb.org/publications/english/Natura_lessons_learnt.pdf

Bell, R.G. (2004) Further up the learning curve: NGOs from transition to Brussels. Environmental Politics 13: 194 215.

Börzel, T. \& Buzogány, A. (2010a) Environmental organisations and the Europeanisation of public policy in Central and Eastern Europe: the case of biodiversity governance. Environmental Politics 19: 708-735.

Börzel, T. \& Buzogány, A. (2010b) Governing EU accession in transition countries: the role of non-state actors. Acta Politica 45: 158-182.

Elliott, C. \& Schlaepfer, R. (2001) Understanding forest certification using the advocacy coalition framework. Forest Policy and Economics 2: 257-266.

EC (2002) Commission working document on Natura 2000. Commission of the European Communities, Brussels, 27 December 2002 [www document]. URL http://ec.europa. $\mathrm{eu} /$ environment/nature/info/pubs/docs/nat2000/2002_faq_ en.pdf

EEA (2007) Europe's environment. The fourth assessment. European Environment Agency, Copenhagen, Denmark [www document] URL http://www.eea.europa.eu/publications/state_ of_environment_report_2007_1

Fairbrass, J. \& Jordan, A. (2001) Protecting biodiversity in the European Union: national barriers and European opportunities? Fournal of European Public Policy 8: 499-518.

Ferranti, F., Beunen, R. \& Speranza, M. (2010) Natura 2000 Network: a comparison of the Italian and Dutch implementation experiences. Fournal of Environmental Policy and Planning 12: 293 314.

Grodzińska-Jurczak, M. \& Cent, J. (2011) Expansion of nature conservation areas: problems with Natura 2000 implementation in Poland. Environmental Management 47: 11-27.

Hall, P.A. (1993) Policy paradigms, social learning, and the state: the case of economic policymaking in Britain. Comparative Politics 25: 275-296.

Hicks, B. (2004) Setting agendas and shaping activism: EU influence on Central and Eastern European environmental movements. Environmental Politics 13: 216-233.

Hiedanpää, J. (2005) The edges of conflict and consensus: a case for creativity in regional forest policy in southwest Finland. Ecological Economics 55: 485-498.

Hysing, E. \& Olsson, J. (2008) Contextualising the advocacy coalition framework: theorising change in Swedish forest policy. Environmental Politics 17: 730-748.

Jordan, A. \& Greenaway, J. (1998) Shifting agendas, changing regulatory structures and the 'new' politics of environmental pollution: British Coastal water policy, 1955-1995. Public Administration 76: 669-694.

Keulartz, J. (2009) European nature conservation and restoration policy-problems and perspectives. Restoration Ecology 17: 446450.

Kluvánková-Oravská, T., Chobotová, V., Banaszak, I., Slavikova, L. \& Trifunovova, S. (2009) From government to governance for biodiversity: the perspective of central and Eastern European transition countries. Environmental Policy and Governance 19: 186196.

Kovács, A., Lovászi, P., Magyar, G., Nagy, K., Szabó, B. \& Szilvácsku, Zs., eds (2002) Proposed Special Protection Areas in Hungary. Budapest, Hungary: Hungarian Ornithological and Conservation Society, MME/BirdLife Hungary: $56 \mathrm{pp}$.

Lawrence, A. (2008) Experiences with participatory conservation in post-socialist Europe. International Fournal of Biodiversity Science and Management 4: 179-186.

Marsh, D. \& Rhodes, R.A.W. (1992) Policy networks in British politics: a critique of existing approaches. In: Policy Networks in British Government, ed. D. Marsh \& R.A.W. Rhodes, pp. 1-26. Oxford, UK: Clarendon Press.

Miles, B.M. \& Huberman, A.M. (1994) Qualitative Data Analysis. Beverly Hills, USA: SAGE Publications.

Niedziałkowski, K., Paavola, J. \& Jędrzejewska, B. (2012) Participation and protected areas governance: the impact of changing influence of local authorities on the conservation of the Bialowieza Primeval Forest, Poland. Ecology and Society 17: 2.

O'Riordan, T \&, Jordan, A. (1996) Social institutions and climate change. In: The Politics of Climate Change: A European Perspective, ed. T. O'Riordan \& J. Jager, pp. 346-360. London, UK: Routledge.

Paavola, J., Gouldson, A. \& Kluvánková-Oravská, T. (2009) Interplay of actors, scales, frameworks and regimes in the governance of biodiversity. Environmental Policy and Governance 19: $148-158$.

Peters, B.G. (1998) Policy networks: myth, metaphor and reality. In: Comparing Policy Networks, ed. D. Marsh, pp. 21-32. Buckingham, UK: Open University Press.

Pinton, F. (2001) Conservation of biodiversity as a European directive: the challenge for France. Sociologia Ruralis 41: 329342.

Rauschmayer, F., van den Hove, S. \& Koetz, T. (2009) Participation in EU biodiversity governance: how far beyond rhetoric? Environment and Planning C: Government and Policy 27: 4258.

Rhodes, R.A.W. (1990) Policy networks. Fournal of Theoretical Politics 2: 293-317.

Sabatier, P.A. (1998) The advocacy coalition framework: revisions and relevance for Europe. Fournal of European Public Policy 5: 98-130.

Sabatier, P.A. \& Jenkins-Smith, H.C. (1999) The advocacy coalition framework: an assessment. In: Theories of the Policy Process. Theoretical Lenses on Public Policy, ed. P.A. Sabatier, pp. 117-168. Boulder, CO, USA: Westview Press.

Schlager, E. (1995) Policy making and collective action: defining coalitions within the advocacy coalition framework. Policy Sciences 28: 243-270.

Smith, A. (2000) Policy networks and advocacy coalitions: explaining policy change and stability in UK industrial pollution policy? 
Environment and Planning C-Government and Policy 18:95114.

Szarka, J. (2010) Bringing interests back in: using coalition theories to explain European wind power policies. Fournal of European Public Policy 17: 836-853.

Tickle, A. \& Clarke, R. (2000) Nature and landscape conservation in transition in central and south-eastern Europe. European Environment 10: 211-219.

Van Koppen, C.S.A. \& Markham, W.T. (2007) Protecting Nature. Organizations and Networks in Europe and the USA. Chaltenham, UK: Edward Elgar Publishing.

Wajrak, A. (2006) Premier: Mamy za dużo chronionej przyrody. Gazeta Wyborcza 7 August 2006.
Weale, A., Pridham, G., Cini, M., Konstadakopulos, D., Porter, M. \& Flynn, B. (2000) Environmental governance in Europe: an ever closer ecological union? Oxford, UK: Oxford University Press.

Weber, N. \& Christophersen, T. (2002) The influence of nongovernmental organisations on the creation of Natura 2000 during the European policy process. Forest Policy and Economics 4: $1-12$.

Ziemińska, J. \& Szulecki, K. (2010) The river that divided a nation: rhetoric, environmental activism and the political controversy over the Rospuda River Valley in Poland. ESPRi Working Paper No 1. February 2010 [www document]. URL http://papers.ssrn.com/sol3/papers.cfm?abstract_id= 1680789 